Drury, A. C., Krieckhaus, J., \& Lusztig, M. (2006). Corruption, democracy, and economic growth. International Political Science Review, 27(2), 121-136.

Fletcher, J., \& Morakabati, Y. (2008). Tourism activity, terrorism and political instability within the commonwealth: The cases of Fiji and Kenya. International Journal of Tourism Research, 10(6), 537-556.

Im, K. S., Pesaran, M. H., \& Shin, Y. (2003). Testing for unit roots in heterogeneous panels. Journal of Econometrics, 115(1), 53-74. Ivanov, S., \& Webster, C. (2013). Tourism's impact on growth: The role of globalisation. Annals of Tourism Research, 41, 231-236.

Kester, J., \& Croce, V. (2011). Tourism development in advanced and emerging economies: What does the travel \& tourism competitiveness index tell us. In Travel and Tourism Competitiveness Report. Geneva: World Economic Forum.

Levin, A., Lin, C.-F., \& James Chu, C.-S. (2002). Unit root tests in panel data: Asymptotic and finite-sample properties. Journal of Econometrics, 108(1), 1-24.

Mehlum, H., Moene, K., \& Torvik, R. (2006). Institutions and the resource curse*. The Economic Journal, 116(508), 1-20.

Mo, P. H. (2001). Corruption and economic growth. Journal of Comparative Economics, 29(1), 66-79.

Plümper, T., \& Martin, C. W. (2003). Democracy, government spending, and economic growth: A political-economic explanation of the Barro-effect. Public Choice, 117(1-2), 27-50.

Rodriguez, F., \& Sachs, J. D. (1999). Why do resource-abundant economies grow more slowly? Journal of Economic Growth, 4(3), 277-303.

Schubert, S. F., Brida, J. G., \& Risso, W. A. (2011). The impacts of international tourism demand on economic growth of small economies dependent on tourism. Tourism Management, 32(2), 377-385.

Seetanah, B. (2011). Assessing the dynamic economic impact of tourism for island economies. Annals of Tourism Research, 38(1), 291-308.

\title{
A new rational IPA and application to cruise tourism
}

\author{
Ramakrishnan Ramanathan ${ }^{\mathrm{a}, *}$, Usha Ramanathan ${ }^{\mathrm{b}}$ \\ ${ }^{\text {a } U n i v e r s i t y ~ o f ~ B e d f o r s h i r e, ~ U n i t e d ~ K i n g d o m ~}$ \\ ${ }^{\mathrm{b}}$ Nottingham Trent University, United Kingdom
}

At least two versions of Importance-performance analysis (IPA), namely the simple IPA and the asymmetric IPA, are available in tourism literature (Albayrak \& Caber, 2015; Pritchard \& Havitz, 2006). The simple IPA involves asking customers their perceptions relating to importance of various performance criteria and how the firm has performed in terms of these criteria (Baker \& Crompton, 2000; Pyo, 2012; Ryan \& Huyton, 2002). The simple IPA assumes a symmetric relationship between performance in terms of various criteria and customer satisfaction. The asymmetric IPA or AIPA (Albayrak \& Caber, 2013; Caber, Albayrak, \& Loiacono, 2013) recognizes that these relationships could be asymmetric and uses the three-factor theory of customer satisfaction (Matzler \& Sauerwein, 2002) to argue for the existence of basic, excitement or performance criteria. While AIPA is an improvement over IPA, AIPA calculations take into account only the magnitude of regression coefficients but not their level of significance. Further, figure 3 of Albayrak and Caber (2015) uses performance in X-axis but impact asymmetry, not importance, in Y-axis. It is not clear why impact asymmetry should be considered synonymous to importance.

In this research note, we propose a variation of AIPA and call it Rational IPA (RIPA). RIPA involves the following steps.

\footnotetext{
* Corresponding author.

E-mail addresses: ram.ramanathan@beds.ac.uk (R. Ramanathan), usha.ramanathan@ntu.ac.uk (U. Ramanathan).
} 
Step 1. Collect relevant data.

Step 2. Run two sets of regressions with overall customer satisfaction as the dependent variable, and performance in terms of various service criteria as independent variables. The first set of regressions is called low performance regressions where only ratings below median levels for each criterion are considered. In contrast, the second set of regressions is called high performance regressions. As highlighted in previous studies (Hartline, Wooldridge, \& Jones, 2003; Ramanathan \& Ramanathan, 2011; Silverman \& Grover, 1995), the criteria are classified based on the results of the two sets of regressions.

(a) A critical criterion remains significant in all regressions (except for low performance in terms of the criterion).

(b) A desirable criterion is significant both for high performance and low performance in terms of the criterion.

(c) A satisfier criterion is significant for high performance regression in terms of the criterion but not significant for low performance.

(d) A dissatisfier criterion is not significant for high performance regression but significant for low performance in terms of the criterion.

(e) All other criteria are neutral criteria.

Step 3. Prepare IPA matrix.

Step 4. Conduct IPA based on the criterion classification (importance) and achievement (performance).

We demonstrate RIPA in the following steps using publicly available online cruise data.

Step 1: Our data has been obtained from www.cruisecritic.co.uk covering the period August 2010August 2012 for Hawaii. Ratings are elicited for nine different performance criteria (listed in Tables 1 and 2) and also for overall customer satisfaction ( 1 for very bad performance and 5 for very good performance).

Step 2: Low and high performance regressions are shown in Tables 1 and 2 respectively. Each of the nine rows in these tables report result of a single regression. All assumptions of regressions have been satisfied but we do not elaborate them here due to lack of space.

First row of Table 1 (Dining) shows results of the regression with low performance in terms of this criterion. We first sorted the whole data using ratings in terms of this criterion, and calculated the median score. We only considered those cruises that registered a rating of less than this median score in terms of dining in the regression. Other rows in Tables 1 and 2 should be interpreted in a similar way. Criteria are classified using the results in Tables 1 and 2.

Table 1

Results of regressions for low performance (below median).

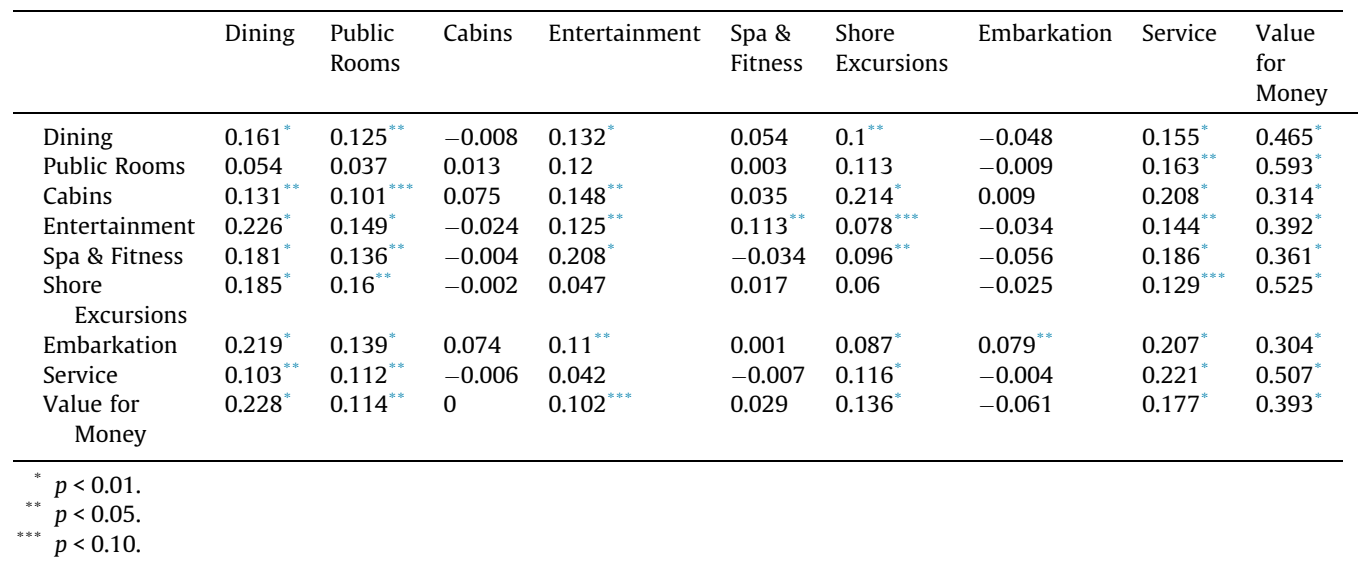


Table 2

Results of regressions for high performance (median and above median).

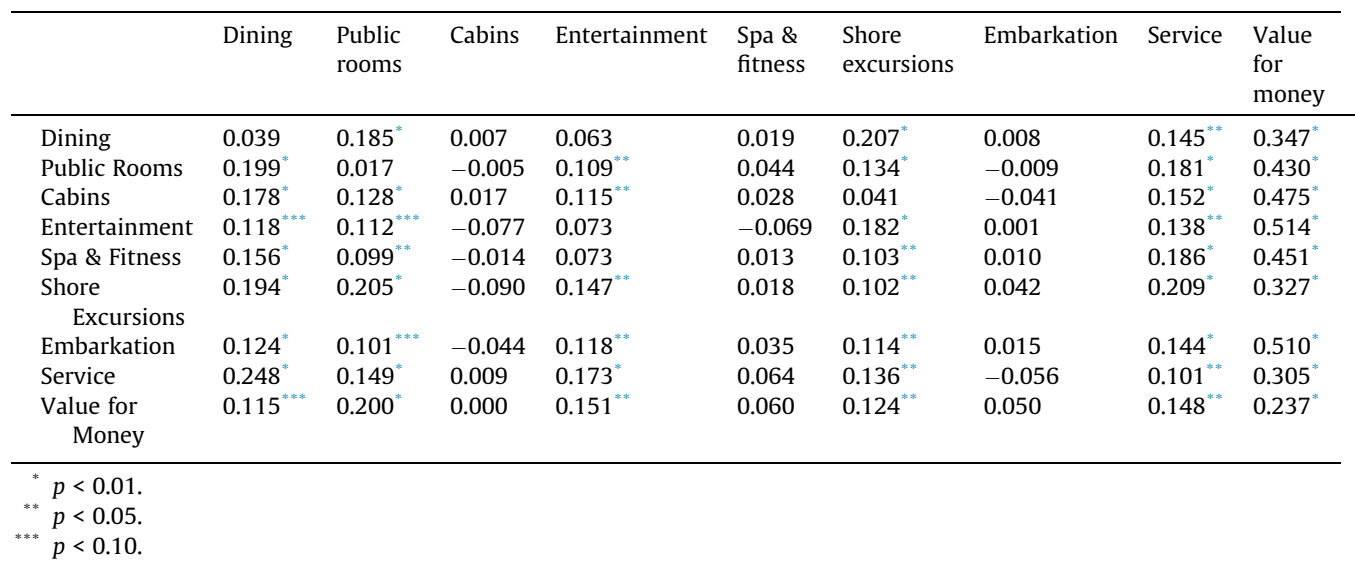

(a) The criteria "Service" and "Value for money" in Tables 1 and 2 are critical as they remain significant in all regressions (see corresponding columns).

(b) These two criteria are also desirable criteria. Thus, a critical criterion is also a desirable criterion but the reverse is not true.

(c) The criterion "shore excursions" is significant for high performance regression in terms of the criterion but not significant for low performance. Hence it is a satisfier.

(d) Dining, Entertainment and Embarkation are dissatisfiers.

(e) Other four criteria are neutral criteria.

Step 3: In RIPA, the level of importance of the criteria are straightforward: critical criteria are the most important, neutral criteria are the least important while the other three sets of criteria (satisfier, dissatisfier and desirable) come in between (Fig. 1).

Step 4: Thus it is clear that the selected cruise-lines are investing the appropriate resources in the right place by performing well in terms of the more important (critical and desirable) criteria. However, they seem to be doing badly in terms of dissatisfier (embarkation) but doing well in terms of neutral criteria.

RIPA helps to obtain more intuitive results. In response to the comment by Lai and Hitchcock (2015) that IPA lacks statistical analysis, the RIPA is grounded in statistics. It involves running a series of regressions. Criteria are classified by looking at levels of significance in the regressions.

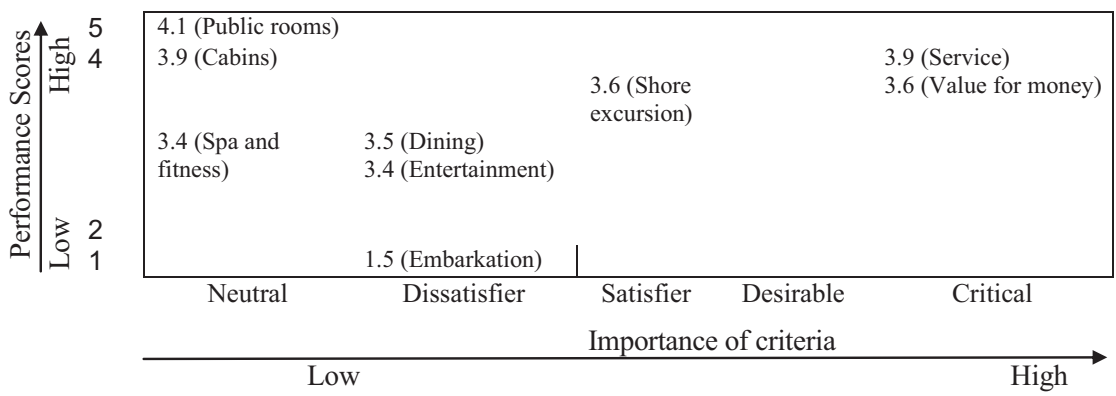

Fig. 1. Rational importance-performance analysis. 
Our study has some limitations. For example, we focused only on Hawaii particular to cruise sector. More locations and sectors should be included in future studies. Additional data sources can help in deriving broader insights. This would help in adding more criteria. Also future studies can help validate RIPA in different contexts.

\section{References}

Albayrak, T., \& Caber, M. (2013). The symmetric and asymmetric influences of destination attributes on overall visitor satisfaction. Current Issues in Tourism, 16(2), 149-166.

Albayrak, T., \& Caber, M. (2015). Prioritisation of the hotel attributes according to their influence on satisfaction: A comparison of two techniques. Tourism Management, 46, 43-50.

Baker, D. A., \& Crompton, J. L. (2000). Quality, satisfaction and behavioral intentions. Annals of Tourism Research, 27(3), 785-804.

Caber, M., Albayrak, T., \& Loiacono, E. T. (2013). The classification of extranet attributes in terms of their asymmetric influences on overall user satisfaction: an introduction to asymmetric impact-performance analysis. Journal of Travel Research, 52(1), $106-116$.

Hartline, M. D., Wooldridge, B. R., \& Jones, K. C. (2003). Guest perceptions of hotel quality: Determining which employee groups count most. Cornell Hotel and Restaurant Administration Quarterly, 44(1), 43-52.

Lai, I. K. W., \& Hitchcock, M. (2015). Importance-performance analysis in tourism: A framework for researchers. Tourism Management, 48, 242-267.

Matzler, K., \& Sauerwein, E. (2002). The factor structure of customer satisfaction: An empirical test of the importance grid and penalty-reward-contrast analysis. International Journal of Service Industry Management, 13(4), 314-332.

Pritchard, M. P., \& Havitz, M. E. (2006). Destination appraisal: An analysis of critical incidents. Annals of Tourism Research, 33(1), 25-46.

Pyo, S. (2012). Identifying and prioritizing destination knowledge needs. Annals of Tourism Research, 39(2), 1156-1175.

Ramanathan, U., \& Ramanathan, R. (2011). Guests' perceptions on factors influencing customer loyalty: An analysis for UK hotels. International Journal of Contemporary Hospitality Management, 23(1), 7-25.

Ryan, C., \& Huyton, J. (2002). Tourists and aboriginal people. Annals of Tourism Research, 29(3), 631-647.

Silverman, S. N., \& Grover, R. (1995). Forming perceptions of overall quality in consumer products: A process of quality element integration Marketing science institute report, 95-103. Cambridge, MA: Marketing Science Institute.

Received 2 August 2016; Revised 23 September 2016; Accepted 3 October 2016

(c) 2016 Elsevier Ltd. All rights reserved. Available online 19 October 2016 http://dx.doi.org/10.1016/j.annals.2016.10.004 